\title{
China's Carbon Market Development and Carbon Market Connection: A Literature Review
}

\author{
Yifei Hua $\mathbb{D}$ and Feng Dong * $\mathbb{D}$ \\ School of Management, China University of Mining and Technology, Xuzhou 221116, China; \\ huamichelle@foxmail.com \\ * Correspondence: cumtdf@cumt.edu.cn; Tel.: +86-158-6216-7293
}

Received: 21 February 2019; Accepted: 25 April 2019; Published: 1 May 2019

\begin{abstract}
As a responsible world power, China has established quantitative carbon emission reduction targets and started to establish carbon trading pilots in 2013. Successfully connection and a certain size of the carbon market can further enhance the liquidity of carbon allowances and, to a certain extent, contribute to the enthusiasm of enterprises to participate. This paper gives an overview of the past operational development of China's eight carbon market pilots, the current problems in the national carbon market, the elements that need to be improved during the establishment process, and the feasibility of future connection between China's carbon market. In addition, the international carbon market was summarized and analyzed. We found that, compared with the already mature carbon market in the world, there is still a big gap between China and these countries' carbon market in various respects, such as the carbon price formation mechanism, the carbon quota allocation, carbon emission coverage sources, and legal and policy systems. Thus, China should manifest the pricing mechanism, unify the allocation of carbon quotas, cover the sources of emissions, introduce clear laws and regulations in the construction of the carbon market, all these will ensure the smooth operation of the national carbon market.
\end{abstract}

Keywords: carbon market; carbon market connection; review

\section{Introduction}

The emission of several greenhouse gases (GHGs), but especially carbon dioxide, is the main cause of global warming [1]. The carbon market is a fast-growing financial market that has emerged in the context of a low-carbon economy. Dealers trade carbon emission rights in the project market or permitted market either by mandatory rules or through spontaneous behaviour. The cost of carbon emission is internalized in the production cost of enterprises through the pricing of carbon emission rights, which is a policy instrument to reduce the emission of greenhouse gas by adopting flexible means of market economy and in a cost-effective manner [2-4]. The carbon market is expected to play a particularly important role in international cooperation in response to global climatic changes. In particular, since the Kyoto Protocol came into effect, many countries worldwide have established carbon trading markets successively to promote the effective reduction of carbon emission, thus realizing the development of a low-carbon economy and the construction of a low-carbon society [5-9]. Although the Kyoto Protocol does not stipulate a compulsory obligation for China to reduce emissions, China has a huge level of carbon emissions not only due to it being the world's largest developing country and having growing energy demand from its rapid economic development but also because of its own unreasonable energy structure [10]. According to BP2018 [11], the total carbon emissions in the world in 2017 are 33,444.0 MT, and China's carbon emissions are 9232.6 MT, accounting for 37.2\%. By contrast, EU and the US accounts for $10.6 \%$ and $15.2 \%$ of the world's carbon emissions, respectively. Based on its standpoint of being responsible for reducing its domestic and global carbon emissions, China has set a 
quantitative target of carbon emissions' reduction and has been successively established pilot projects for carbon trading since 2013, which shows that China has the courage to shoulder its international responsibilities [12-15]. In the US-China Joint Presidential Statement on Climate Change, Chairman Xi Jinping pledges that China will begin to build a national carbon market in 2017, as the country's largest source department of carbon emission [16]. In December 2017, the electric power industry became the breakthrough of the national trading market of carbon emission $[17,18]$. The smooth operation of the national carbon market will bring economic and environmental benefits and help China hit the national target of emission reduction [19]. The task of establishing a national registration system and a national trading system of carbon emission rights will be undertaken by the Hubei Pilot Project of Carbon Trading and the Shanghai Pilot Project of Carbon Trading, respectively [20]. The national carbon market will gradually cover such key emission industries as petrochemicals, chemicals, steel, and aviation [21]. China plans to abolish the free carbon quota allocation by 2020, thus entering the stage of implementation and perfection of carbon trading [17].

The international carbon market has developed rapidly since the European Union Emissions Trading System (EU ETS) began operations in 2005. According to the ICAP (2018) [22], as of now, there are 21 carbon emission trading systems in operation around the world. The carbon market covers nearly $15 \%$ of global carbon emissions. In terms of carbon prices, the prices of China's seven carbon trading pilots are at uneven level, and the price range is between US\$1 and US\$9/ton, while the carbon prices of EU ETS and CA CAT are \$16/ton and \$15/ton, respectively [23]. The Chinese carbon market (CCM) is expected to cover 3 to 4 billion tons of carbon dioxide emissions. By the end of 2018, China's carbon market volume reached 270 million tons of carbon dioxide emissions, and the turnover exceeded 6 billion yuan [24].

Furthermore, with the development of the carbon market and the need for cooperative emission reduction, the trend of establishing a global carbon market is becoming more and more obvious. The 16th United Nations Framework Convention on Climate Change (UNFCCC) Conference of the Parties (COP16), which was held in Cancun in 2010, first presented a discussion on the international carbon market under the Paris Agreement. Its intention is to establish one or more market mechanisms to increase the cost-effectiveness of the carbon market [25]. Thus, along with the gradual rise of the global carbon market, many relevant studies have emerged and many countries are exploring the possibility of linking. However, the existing literature has limited to investigating one or more carbon markets, which has not yet involved the carbon market connection. Based on the research results of a large number of literatures and reports, this paper summarizes the basic state of CCM and compares it with EU ETS and CA CAT. In addition, from the perspectives of carbon price, carbon allowance, total emissions and sources of emissions as well as related laws, we put forward the elements that need to be perfected before the CCM unification. Lastly, the feasibility of integrating the CCM into the global carbon trading system is analyzed and specific measures are proposed. Our study would not only improve the research on carbon market connection but also provide some references for other countries' policy making on carbon markets.

The remainder of the paper is organized as follows. Section 2 presents the background overview. Section 3 describes the development of the pilot areas of carbon trading in China. Section 4 discusses elements upon the establishment of a unified Chinese market. The Outlook of connection between the Chinese and the world carbon market is provided in Section 5. Finally, we conclude this study.

\section{Background Overview}

The presence of rich energy resources, such as minerals and oils, as well as numerous energy-intensive industries, indicates that China's carbon emission trading market has great potential for development. To achieve a nationwide carbon emissions' trading mechanism, a series of long-term and short-term national targets for carbon market building has been set up; this is both a binding force and a catalyst for the carbon market $[26,27]$. A large number of academic achievements and pilot experiences have enhanced China's confidence in establishing a national carbon market. Most 
scholars believe that China should seize this opportunity to renovate and upgrade domestic backward production capacity, ease the bottleneck constraints of the ecological environment on economic and social development, and reduce carbon emissions fundamentally [28,29]. However, the carbon market will be affected not only by market dynamics but also by the changing external environment, such as international climate negotiations, national quota allocation plans, and financial crises. Meanwhile, the close relationship between carbon quota prices and prices of coal, oil, natural gas, and electricity in the energy market, together with the uncontrollable nature of the weather, have also led to certain specialties and complexities in the carbon emission trading market [1,30-35].

Following the Shenzhen carbon emissions trading pilot built in 2013, seven pilots in Shanghai, Beijing, Guangdong, Tianjin, Hubei, Chongqing, and Fujian in China have been built successively to shape a nationwide unified carbon emissions trading market with accumulating capacities and practical experiences; thus, the young CCM is growing gradually on the right track [34,36]. Though the national carbon emissions trading market has already started operation, the national unified carbon market is targeted merely at the power industry; hence, the pilots have withdrawn from the historical stage after coexisting with the national market for a period of time [37]. Considering the uneven regional development and imbalance of industrial structures, the 8 pilots were selected purposely in eastern, central, and western parts of China with different economic development and geographical locations. This was done so as to adapt to the phased and regional emission reduction targets, to prevent the release of partial policies when initiating the national carbon trading market, and to avoid neglecting differences in economic, social, energy, and environmental aspects of China's provinces and cities $[28,38,39]$. In addition, with China's power industry being taken as a breakthrough in launching the national carbon emission trading market at the end of 2017, all these efforts highlight the determination of the Chinese government in engaging in global climate governance and achieving emission reduction targets via market means $[4,39]$. Similar to the international classification of carbon markets, China's carbon market is also divided into a mandatory carbon market and a voluntary carbon market. In the mandatory carbon market, the regulatory authorities issue annual emission reduction quotas to participating enterprises; if the final amount of emissions of a participator exceeds the quotas they receive, extra quotas can be purchased from participators with surplus quotas. The voluntary carbon market is an important complement to the eight carbon emissions' pilots, as it is the complementary trading market set up by the state to guide clean energy projects for profit and to receive additional economic and corporate social responsibility benefits by selling China-approved self-reduction of carbon emissions.

The regional carbon market may become the future development trend of the world's climate governance; an effectively connected carbon market of a certain scale can inspire the enthusiasm of market participants, thus promoting market liquidity and activity [40]. The liquidity is related closely to the carbon market efficiency [41]. However, after studying the market efficiency of CCM, Zhao et al. [42] found that although the market design of CCM has achieved initial results, while unreasonable caps and quotas as well as vague reward and punishment mechanisms cannot stimulate the participation of enterprises, thereby resulting in low transaction enthusiasm. Thus, as the world's largest potential market for carbon emissions trading, it is necessary to improve the domestic one while strengthening the research on the docking of the carbon market. When the national carbon market is on the right track, integrating into the global carbon market can decrease significantly the consumption of fossil energy such as coal in China, lower the consumption of carbon-intensive energies, and improve the energy structure, thus reducing China's energy intensity and carbon intensity [29]. The launch of the national carbon emissions' trading market will also serve as the necessary foundation for China's integration into the global carbon trading system; nevertheless, the construction of China's carbon trading market lags dramatically behind that of developed countries and even some developing countries. Non-centralized geographical locations of carbon emissions' trading pilots, enterprises in carbon emissions would lack of activity, lack of liquidity of carbon quotas, and sluggish trading volume, are some of the obstacles to the development of China's carbon market mechanism, making it difficult 
for China to obtain pricing power and initiative in the international carbon trading market $[27,43,44]$. Therefore, the questions of how can China develop its independent carbon market pilots smoothly into a national unified carbon market, extend the established carbon market of the national power industry to more key emission industries, and, eventually, promote the integration of the national carbon trading market into the global carbon market are need to be addressed now.

\section{An Overview of the Development of the Pilot Areas of Carbon Trading in China}

\subsection{The Legal Basis of the Pilot Areas}

A mature system of policies, laws, and regulations is the basis for the healthy and stable development of the carbon market [27]. Most of the countries with mature carbon markets have established the legal status of the carbon market at the macro level. The legal attributes of the carbon quota and the scope of responsibility of relevant subjects provide further legal guarantee for the concrete operation of the carbon market $[45,46]$. However, among the eight pilot markets in China, the legal hierarchy of the system of carbon emission trading varies from one pilot market to another. Only Shenzhen and Beijing carry out operations in accordance with national legislation, supplemented by local rules and regulations. The other six pilot markets were established according only to local administrative laws and regulations [47]. The standards and methods concerning quota allocation and testing, reporting, and accounting are only normative documents formulated and issued by various local Development and Reform commissions. Due to the absence of overall guidance of legislation at the national level, the difference in the standards of local legislation will become an obstacle to the legal application for the connection of pilot carbon markets [44].

Although China launched a unified carbon market with the electric power industry as the pilot industry throughout the country at the end of 2017, only The Interim Measures for the Administration of Carbon Emission Trading promulgated by the National Development and Reform Commission in 2014 is now a regulatory framework of the central government, and a regulatory framework and a legal supervisory system are absent at the national level. Due to the difference in the actual conditions among various pilot projects, there is also a slight difference among local administrative measures, so the legal basis of the formation of the carbon market in China is short of the effective support of an upper-level law $[48,49]$. Owing to the lack of the legal basis at the unified level and the lack of a unified standard among local laws and regulations, various carbon pilot-projects would face a lot of administrative interference, so that they cannot give full play to the flexibility of the markets. Moreover, the generally lax penalties of various local laws and regulations for breaches of carbon trading contracts will prevent carbon market laws and regulations from showing their due legal binding force.

\subsection{Modes of Quota Allocation in Pilot Areas}

As the core of carbon emission mechanism design, the quota mechanism will affect the compliance cost of each enterprise under the mechanism [50]. The rules of the Grandfather method (historical emission method) are relatively mild, and the rules of the industry benchmark method are stricter [51]. In the various trading pilot-areas, Beijing, Tianjin, Guangdong, and Chongqing adopt both the historical emission method and industry benchmark method. In addition to the above two methods, Shanghai, Hubei, and Fujian also adopt the historical intensity method for some industries, with different measuring methods corresponding to different industries. Shenzhen takes the baseline method as the main method and measures the carbon quota in some industries by using the intra-industry competition game method. With the exception of Chongqing, all other pilot areas basically adopt the baseline method for the electric power, cement, and other industries that have good data conditions and have already taken their initial shapes. The difference in industrial coverage, access thresholds, etc., among various pilot areas reflects each pilot area have different targeted designing priorities [46]. The differences in the industrial structures of various pilot areas leads to differences in the sources of emission they control, in which the electric power, thermal power, cement, petrochemicals and 
transportation industries have the highest coverage. The pilot project in Shanghai has the most extensive coverage of industries. The differences in the coverage of various pilot areas will lead to differences in the emission costs of various industries in the operation of the national carbon market, which will affect the competitiveness of the same industry in different pilot areas. With the exception of the pilot project in Chongqing, which has incorporated all six greenhouse gases covered by Kyoto Protocol into its control, all other pilot areas only have carbon dioxide as a single controlled gas. The pilot projects in Beijing, Tianjin, Guangdong, Chongqing, and Fujian have adopted a single access standard, whereas the pilot projects in Shanghai and Hubei have access standards that vary from industry to industry. Shenzhen has incorporated the size of public buildings into its measurement criteria. With regard to the threshold of incorporation, Guangdong and Tianjin prefer the model of industrial economic development, with a lot of industrial enterprises, so they have a high threshold for the emission of enterprises incorporated into their control. In contrast, in the service industry of Beijing and Shenzhen as the pioneer of their economic development, the carbon emission of an individual enterprise is not high, so the threshold of incorporation is low, but the number of enterprises covered is large [18]. By comparing the pilot projects of carbon trading in China with the carbon emission trading system of EU ETS and California (CA CAT), we can find that the quota measurement method used at each stage in EU ETS is uniform and that EU ETS and CA CAT now adopt the industry benchmark method. The industries covered by the above two are also largely concentrated in either heavy industry or high-emission industries, but the gases controlled by them are more diversified (see Table 1).

Because the eight pilot projects are still at the early stage of development, in order to attract enterprises and enhance their enthusiasm to participate in carbon trading, the pilot projects mainly adopt a mode of free quota allocation, plus a small amount of paid auction shares. The pilot projects in Guangdong and Hubei have an obviously higher auction proportion than other pilot projects [49]. In terms of offset mechanism, the offset ratio of CCER (China Certified Emission Reduction) is relatively high, which is helpful to enable the provinces and municipalities outside the pilot areas to participate actively in the carbon market and is also an effective means for the smooth transition to the national carbon market at present [34]. In terms of penalty mechanism, the specific penalty modes of various pilot projects are different, and they can be classified roughly into three types: cash penalty, quota or emission penalty, and non-enjoyment of policy benefit. Shanghai, Hubei, and Guangdong adopt more than one penalty mode. The differences in penalty mode may bring about excessive speculative behaviour of enterprises that maximize their profits by choosing to breach the contract on their initiatives and will ultimately knock the market mechanism of the national carbon market out of balance. By comparing EU ETS with CA CAT, we can see that the quota allocation modes adopted by various pilot projects in China at present are similar to the mixed modes of free allocation and paid allocation adopted in other carbon markets at the initial stage [44], although the offset mode in the EU is more diversified. Table 2 summarizes the difference in quota allocation, offset mechanism, and penalty measures among the pilot areas of carbon trading in China and the contrast between China and EU ETS and CA CAT in this regard. 
Table 1. Comparison of evaluating method, industry distribution, regulated emission, and admittance criterion among Chinese ETS pilots, EU ETS, and CA CAT.

\begin{tabular}{|c|c|c|c|c|c|c|c|}
\hline \multirow[b]{2}{*}{ Pilot } & \multicolumn{4}{|c|}{ Quota Measurement Methods } & \multirow[b]{2}{*}{ Covered Industries } & \multirow[b]{2}{*}{ Controlled Gas } & \multirow[b]{2}{*}{ Threshold } \\
\hline & $\begin{array}{l}\text { Historical } \\
\text { Emissions }\end{array}$ & $\begin{array}{c}\text { Industry } \\
\text { Benchmarks }\end{array}$ & $\begin{array}{l}\text { Historical } \\
\text { Intensities }\end{array}$ & Game Playing & & & \\
\hline Beijing & $\sqrt{ }$ & $\sqrt{ }$ & & & $\begin{array}{c}\text { Electricity and heat, cement, petrochemical and other } \\
\text { industrial sectors, service industries, urban public } \\
\text { transport, power transmission, manufacturing, and } \\
\text { large public buildings }\end{array}$ & $\mathrm{CO}_{2}$ & Carbon emissions > $5000 \mathrm{t} / \mathrm{year}$ \\
\hline Tianjin & $\begin{array}{l}\text { For carbon } \\
\text { emission stock }\end{array}$ & $\begin{array}{l}\text { For carbon } \\
\text { emission } \\
\text { increment }\end{array}$ & & & $\begin{array}{l}\text { Steel, chemical, power and heat, petrochemical, oil and } \\
\text { gas development }\end{array}$ & $\mathrm{CO}_{2}$ & Carbon emissions $>20,000 \mathrm{t} /$ year \\
\hline \multirow{3}{*}{ Shanghai } & & $\sqrt{ }$ & & & Electricity and heat, automotive glass & \multirow{3}{*}{$\mathrm{CO}_{2}$} & \multirow{3}{*}{$\begin{array}{l}\text { Water transport: standard coal } \\
\text { consumption }>50,000 \mathrm{t} / \text { /year or } \\
\text { carbon emissions }>100,000 \mathrm{t} / \mathrm{year} \\
\text { Other industries: standard coal } \\
\text { consumption }>5000 \mathrm{t} \text { tyear or } \\
\text { carbon emissions }>10,000 \mathrm{t} / \text { year }\end{array}$} \\
\hline & & & $\sqrt{ }$ & & $\begin{array}{l}\text { Aviation, port, water transport, tap water supply; } \\
\text { companies with high carbon emissions and no more } \\
\text { than } 3 \text { products }\end{array}$ & & \\
\hline & $\sqrt{ }$ & & & & $\begin{array}{l}\text { Shopping malls, hotels, business offices, airports; } \\
\text { companies with special products or ineffective use of } \\
\text { historical emissions or historical intensities' methods }\end{array}$ & & \\
\hline Shenzhen & & $\begin{array}{l}\text { For mainly } \\
\text { industry }\end{array}$ & & $\begin{array}{l}\text { For some } \\
\text { enterprises in the } \\
\text { same industry }\end{array}$ & 26 industries (electricity and heat, public buildings, etc.) & $\mathrm{CO}_{2}$ & $\begin{array}{l}\text { Industry: Carbon emissions }>3000 \\
\mathrm{t} / \mathrm{year} \text { Public building area }>10,000 \\
\mathrm{~m}^{2} \text { Other industries not included } \\
\text { can voluntarily join the carbon } \\
\text { trading market. }\end{array}$ \\
\hline Guangdong & $\sqrt{ }$ & $\sqrt{ }$ & & & Electricity, steel, cement, petrochemical & $\mathrm{CO}_{2}$ & Carbon emissions $>20,000 \mathrm{t} / \mathrm{year}$ \\
\hline \multirow[b]{3}{*}{ Hubei } & & $\sqrt{ }$ & & & Cement, electricity and heat & \multirow{3}{*}{$\mathrm{CO}_{2}$} & \multirow{3}{*}{$\begin{array}{l}\text { Metal products, paper industry and } \\
\text { power industry: standard coal } \\
\text { consumption }>10,000 \mathrm{t} / \text { year Other } \\
\text { industries: standard coal } \\
\text { consumption }>60,000 \mathrm{t} / \mathrm{year}\end{array}$} \\
\hline & & & & $\sqrt{ }$ & $\begin{array}{c}\begin{array}{c}\text { Glass and other building materials, ceramic } \\
\text { manufacturing }\end{array} \\
\text {. }\end{array}$ & & \\
\hline & $\sqrt{ }$ & & & & $\begin{array}{l}\text { Automotive, general equipment manufacturing, steel, } \\
\text { petrochemical, chemical fibre, chemical, non-ferrous } \\
\text { metals and other metal products, food and beverage } \\
\text { manufacturing, pharmaceutical, paper-making }\end{array}$ & & \\
\hline Chongqing & $\begin{array}{l}\text { For mainly } \\
\text { industry }\end{array}$ & $\begin{array}{l}\text { For carbon } \\
\text { emission } \\
\text { increment }\end{array}$ & & & $\begin{array}{l}\text { Electrolytic aluminium, ferroalloy, calcium carbide, } \\
\text { caustic soda, cement, steel }\end{array}$ & $\begin{array}{l}\text { Six greenhouse gases covered in } \\
\text { the Kyoto Protocol }\end{array}$ & Carbon emissions $>20,000 \mathrm{t} /$ year \\
\hline
\end{tabular}


Table 1. Cont.

\begin{tabular}{|c|c|c|c|c|c|c|c|}
\hline \multirow[b]{2}{*}{ Pilot } & \multicolumn{4}{|c|}{ Quota Measurement Methods } & \multirow[b]{2}{*}{ Covered Industries } & \multirow[b]{2}{*}{ Controlled Gas } & \multirow[b]{2}{*}{ Threshold } \\
\hline & $\begin{array}{l}\text { Historical } \\
\text { Emissions }\end{array}$ & $\begin{array}{c}\text { Industry } \\
\text { Benchmarks }\end{array}$ & $\begin{array}{l}\text { Historical } \\
\text { Intensities }\end{array}$ & Game Playing & & & \\
\hline \multirow{3}{*}{ Fujian } & & $\sqrt{ }$ & & & $\begin{array}{c}\text { Power generation, cement, electrolytic aluminium, } \\
\text { flat glass }\end{array}$ & \multirow{3}{*}{$\mathrm{CO}_{2}$} & \multirow{3}{*}{$\begin{array}{c}\text { Standard coal consumption > } \\
10,000 \mathrm{t} / \text { year Carbon emissions > } \\
26,000 \mathrm{t} / \text { year }\end{array}$} \\
\hline & & & $\sqrt{ }$ & & $\begin{array}{l}\text { Power grid, copper smelting, steel, chemical, crude oil } \\
\text { processing, ethylene, pulp manufacturing, machine } \\
\text { paper and cardboard, air passenger transportation, air } \\
\text { cargo transportation, airports, building ceramics }\end{array}$ & & \\
\hline & $\sqrt{ }$ & & & & Daily ceramics and sanitary ceramics, gardening & & \\
\hline EU ETS Phase I\&II & $\sqrt{ }$ & & & & $\begin{array}{l}\text { Electricity, petrochemical, steel, building materials, } \\
\text { paper-making and aviation }\end{array}$ & $\mathrm{CO}_{2}$ & \multirow{2}{*}{$\begin{array}{l}\text { Each industry has different } \\
\text { standards }\end{array}$} \\
\hline EU ETS Phase III & & $\sqrt{ }$ & & & $\begin{array}{l}\text { Electricity, paper, petrochemical, steel, building } \\
\text { materials, chemicals, aviation and aluminium }\end{array}$ & $\mathrm{CO}_{2}, \mathrm{NO}_{2}, \mathrm{PECs}$ & \\
\hline CA CAT & & $\sqrt{ }$ & & & $\begin{array}{l}\text { Electricity, oil refining, oil and gas, glass, food } \\
\text { processing, cement and transportation }\end{array}$ & $\begin{array}{l}\text { Six greenhouse gases covered in } \\
\text { the Kyoto Protocol, Nitrogen } \\
\text { trifluoride and other } \\
\text { fluorinated greenhouse gases }\end{array}$ & Carbon emissions $>20,000 \mathrm{t} /$ year \\
\hline
\end{tabular}

Source: $[18,27,30,34,52-54]$. 
Table 2. Comparison of quota allocation, offset mechanism, restriction measure among Chinese ETS pilots, EU ETS, and CA CAT.

\begin{tabular}{|c|c|c|c|c|}
\hline \multirow{2}{*}{ Pilots } & \multicolumn{2}{|c|}{ Allocation Method } & \multirow[b]{2}{*}{ Offset Mechanism } & \multirow{2}{*}{ Punitive Measures } \\
\hline & Free & Paid & & \\
\hline Beijing & $\begin{array}{l}\text { Distribution based on the } \\
\text { previous year's emission quotas }\end{array}$ & $\begin{array}{l}\text { The auction ratio not exceeding } \\
5 \% \text { of the total annual amount }\end{array}$ & $\begin{array}{l}\text { Not exceeding } 5 \% \text { of emissions } \\
\text { and not exceeding half of local } \\
\text { CCERs }\end{array}$ & $\begin{array}{l}\text { Companies failing to fulfil their obligation shall pay a } \\
\text { fine of } 3-5 \text { times based on the average market price of } \\
\text { carbon quotas; companies failing not deliver or confirm } \\
\text { carbon emissions reports shall pay a fine of not more } \\
\text { than } 50,000 \text { yuan. }\end{array}$ \\
\hline Tianjin & $\begin{array}{l}\text { Free allocation for annual } \\
\text { increment }\end{array}$ & & No more than $10 \%$ of emissions & $\begin{array}{l}\text { Companies failing to complete MRV shall not enjoy } \\
\text { government-related preferential policies or investments. }\end{array}$ \\
\hline Shanghai & & $\begin{array}{l}\text { Enterprises autonomously } \\
\text { choose whether to participate in } \\
\text { carbon quota auctions }\end{array}$ & $\begin{array}{c}\text { No more than } 5 \% \text { of carbon } \\
\text { quotas }\end{array}$ & $\begin{array}{l}\text { Companies failing to complete or confirm the carbon } \\
\text { emission report, or performance contract shall pay a fine } \\
\text { of } 10,000-30,000 \text { yuan, not more than } 50,000 \text { yuan, and } \\
50,000-100,000 \text { yuan, shall be recorded in the credit } \\
\text { record, and shall not enjoy government-related } \\
\text { preferential policies or investment. }\end{array}$ \\
\hline ShenZhen & $\begin{array}{c}\text { Including pre-allocated quotas, } \\
\text { new enterprise reserve quotas, } \\
\text { and adjusted quota allocations: } \\
\text { allocated once a year }\end{array}$ & $\begin{array}{l}\text { The auction rate less than } 3 \% \text { of } \\
\text { the total annual quota B. Quotas } \\
\text { can be sold at a fixed price }\end{array}$ & No more than $10 \%$ of emissions & $\begin{array}{l}\text { Companies failing to fulfil their obligations shall pay a } \\
\text { three-fold fine based on the average market price of } \\
\text { carbon quotas. }\end{array}$ \\
\hline Guangdong & $\begin{array}{l}95 \% \text { free quota for power } \\
\text { companies; } 97 \% \text { free quota for } \\
\text { iron, petrochemical, and cement } \\
\text { companies }\end{array}$ & $\begin{array}{l}2 \text { million t quota for auction is } \\
\text { planned }\end{array}$ & $\begin{array}{l}\text { Not exceeding } 10 \% \text { of emissions } \\
\text { and not exceeding half of local } \\
\text { CCERs }\end{array}$ & $\begin{array}{l}\text { Companies refusing to complete the performance shall } \\
\text { be deducted twice the amount of the uncompleted part } \\
\text { of the performance in the second year and shall pay a } \\
\text { fine of } 50,000 \text { yuan }\end{array}$ \\
\hline Hubei & $\begin{array}{l}\text { Including annual initial quota, } \\
\text { new reserve quota, and } \\
\text { government reserve quota: } \\
\text { allocated once a year }\end{array}$ & $\begin{array}{l}20 \% \text { of the total annual carbon } \\
\text { quotas is required for auction }\end{array}$ & $\begin{array}{l}\text { Not exceeding } 10 \% \text { of the } \\
\text { carbon quota; } 1 \mathrm{t} \text { CCER is } \\
\text { equivalent to } 1 \mathrm{t} \text { emission quota }\end{array}$ & $\begin{array}{l}\text { Companies refusing to complete the performance shall } \\
\text { be deducted twice the quota for uncompleted } \\
\text { performance in the second year, and shall pay a fine of } \\
1-3 \text { times the average market price of the quota. }\end{array}$ \\
\hline
\end{tabular}


Table 2. Cont.

\begin{tabular}{|c|c|c|c|c|}
\hline \multirow{2}{*}{ Pilots } & \multicolumn{2}{|c|}{ Allocation Method } & \multirow{2}{*}{ Offset Mechanism } & \multirow{2}{*}{ Punitive Measures } \\
\hline & Free & Paid & & \\
\hline Chongqing & \multicolumn{2}{|c|}{ All for free allocation } & $\begin{array}{l}\text { Otherwise regulated by the } \\
\text { authority }\end{array}$ & $\begin{array}{l}\text { Companies refusing to complete the performance shall } \\
\text { be reported publicly for the violations and deprived of } \\
\text { government-related preferential policies or investments. }\end{array}$ \\
\hline Fujian & \multicolumn{2}{|c|}{ All for free allocation } & $\begin{array}{l}\text { Not more than } 10 \% \text { of the } \\
\text { confirmed emissions in the } \\
\text { current year, forestry carbon } \\
\text { sink (FFCER) recorded with } \\
\text { CCER and Fujian Carbon } \\
\text { Exchange can be used to offset }\end{array}$ & $\begin{array}{l}\text { Quota penalties and fines for companies refusing to fulfil } \\
\text { their payment obligations: disciplinary punishment for } \\
\text { companies refusing to perform their duties }\end{array}$ \\
\hline $\begin{array}{c}\text { EU ETS } \\
\text { Phase I \& II }\end{array}$ & $\begin{array}{l}\text { Phase I }>95 \% \\
\text { Phase II }>90 \%\end{array}$ & $\begin{array}{c}\text { Phase I }<5 \% \\
\text { Phase II }<10 \%\end{array}$ & & \\
\hline $\begin{array}{l}\text { EU ETS } \\
\text { Phase III }\end{array}$ & \multicolumn{2}{|c|}{$\begin{array}{c}\text { Achieve at least } 50 \% \text { of auctions and plan to achieve a } 100 \% \text { quota } \\
\text { auction for the power industry by } 2020\end{array}$} & $\begin{array}{l}\text { Partial offset by JI and CDM } \\
\text { credits is allowed; yet the offset } \\
\text { should not exceed 50\% of } \\
\text { emissions during 2008-2020 }\end{array}$ & $\begin{array}{l}\text { Companies failing to fulfil their obligations shall be } \\
\text { fined } 100 \text { euros per } t \text { carbon quota. }\end{array}$ \\
\hline CA CAT & $\begin{array}{l}\text { Public utilities and natural gas } \\
\text { distributors }\end{array}$ & $\begin{array}{l}\text { Auction Also can sell at a fixed } \\
\text { rate }\end{array}$ & No more than $8 \%$ of emissions & $\begin{array}{l}\text { Companies failing to fulfil their obligations shall pay a } \\
\text { four-fold fine for excessive emissions. }\end{array}$ \\
\hline
\end{tabular}


From the operation feedback of the eight carbon pilot-projects, we can learn that the quota allocation effect of various pilot projects is not ideal. In the historical emission method, the upper limit of carbon emission needs to be established on the basis of historical emission data of covered enterprises, but most Chinese companies under emission control did not consciously record emission data in details at an earlier time. This may lead to poor accuracy in the allocation of emission quotas [27]. Moreover, relying blindly on historical data will also lead to backward production technology. Enterprises with a high historical emission will get a larger carbon quota than will those with better production technology and a more obvious effect of emission reduction. Although the industry benchmark method can alleviate the above defect to a certain extent, it has a high demand for the data provided by enterprises under emission control, and the large-scale implementation of the industry benchmark method in the CCM at the present stage will be very costly [52]. In conclusion, a unified initial allocation standard of carbon emission rights has not yet come into being in the national carbon market, so that enterprises in different areas tend to, driven by interest, take advantage of the differentiation of quota allocation to escape their responsibility for emission reduction.

\subsection{Trading Conditions in Pilot Area}

At present, the carbon quota trading prices of the eight carbon trading pilot-projects in China are quite different [28], showing a trend of drastic fluctuation and decline (see Figure 1). The pilot trading prices of the pilot projects are concentrated mostly within the price range of 10-50 yuan; Beijing and Shenzhen have relatively high transaction prices, Chongqing has the lowest transaction price, the pilot trading prices of Shenzhen and Guangdong fluctuate considerably, the pilot trading price of Hubei shows the most stable trend, and the future trend of carbon quota transaction prices in various pilot areas is unclear $[18,46]$. From the perspective of trading volume, the performances of the pilot projects in Guangdong and Hubei are obviously better than are those of other pilot projects, some pilot projects even have zero trading volume [54], and the concentration of the time points of the trading is also heterogeneous among various pilot projects (see Figure 2). The total volume of carbon trading of the three pilot projects in Hubei, Guangdong, and Shenzhen accounts for more than $70 \%$ of the national carbon market trading (see Figure 3), which is obviously superior to that of the other pilot projects [45]. Therefore, the development of various carbon trading pilot-projects in China is obviously unbalanced, showing the significant regional difference, and the overall market trading mechanism is ineffective [38]. The huge difference in the transaction price and trading volume of carbon quota is likely to bring about the risk of carbon leakage and make it more difficult for the national carbon market to realize the trading among various pilot projects and between the pilot projects and the central government. 


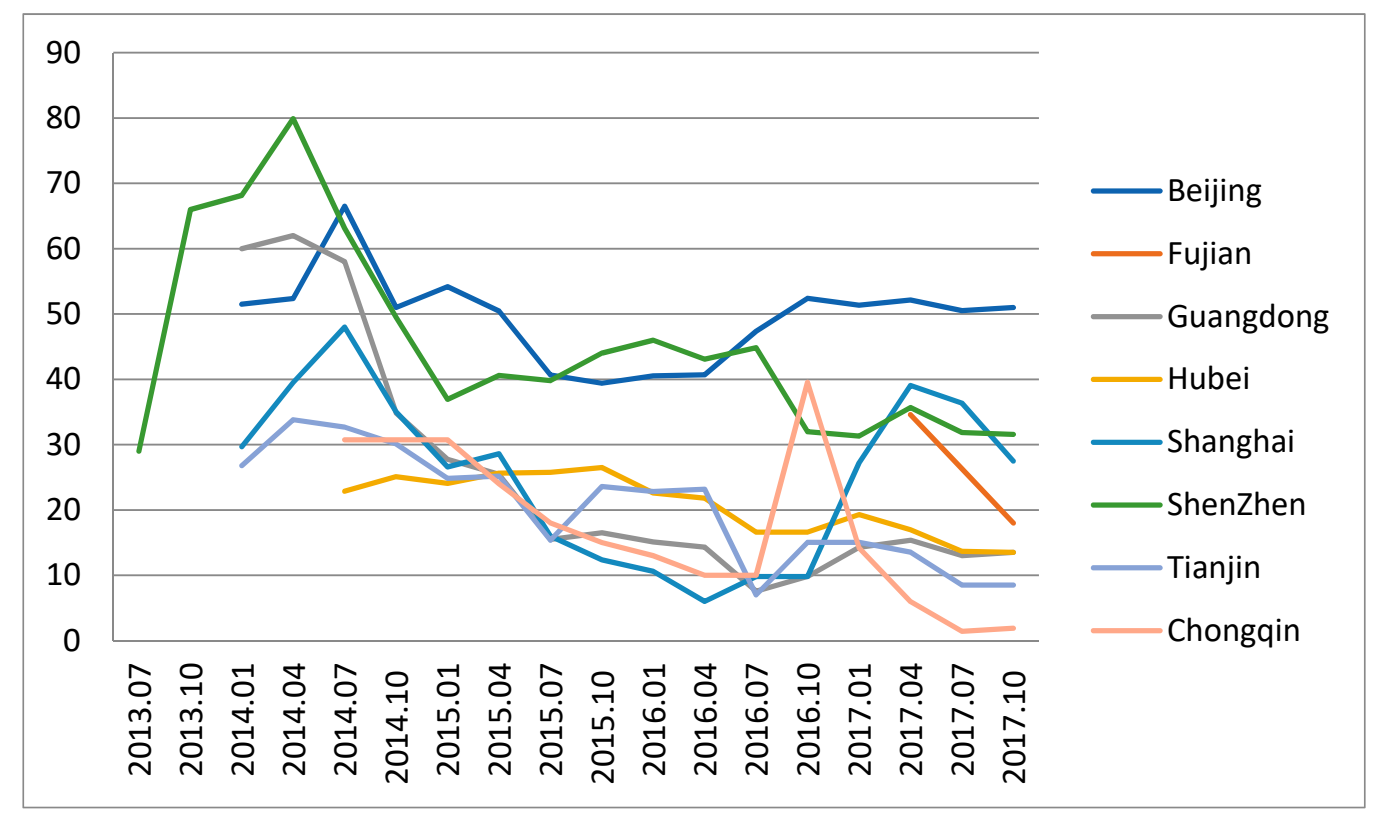

Figure 1. Quota price in first trading day of each quarter during 2013 to 2017 in Chinese ETS pilots [55].

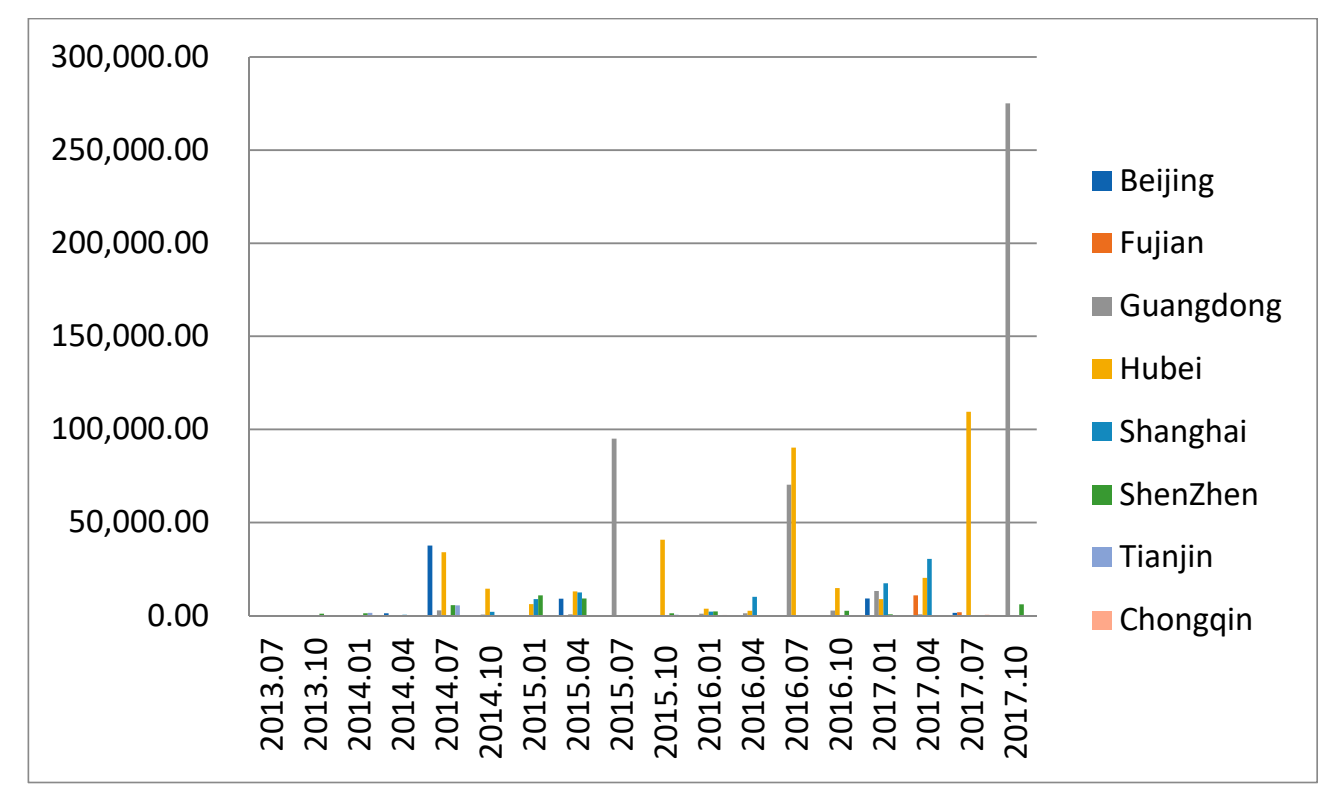

Figure 2. Trading volume in first trading day of each quarter during 2013 to 2017 in Chinese ETS pilots [55]. 


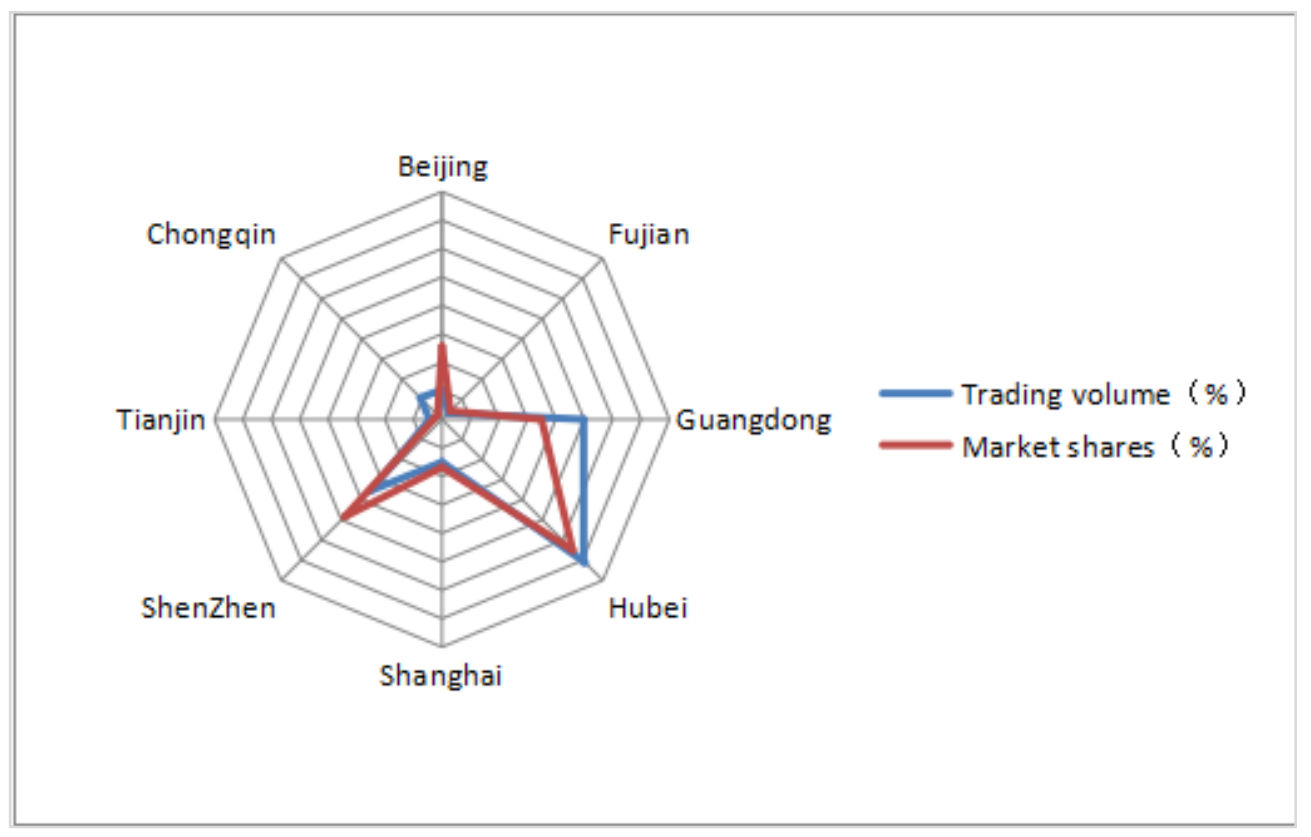

Figure 3. Distribution of carbon trading volume and carbon trading market shares for each pilot [55].

After measuring the status of carbon market trading and the industrial structures of the pilot areas, China has selected the pilot project in Hubei to build the national carbon finance centre because it has brisk market trading [56] and the characteristics of its economic development and industrial structure are the most similar to those of the overall situation of the country [19]. However, the pace of development of the carbon finance in various pilot projects is still slow, making the carbon market fall short of sustained development momentum [27]. At present, the carbon finance of China still lacks detailed institutional arrangements, which makes financial supervision of the carbon market more difficult [57], and the government-led carbon finance market still exacerbates the characteristics of the CCM with poor liquidity and unstable carbon quota prices [58]. Sufficient liquidity of market and accuracy of carbon pricing are essential factors to ensure the smooth operation of the carbon market [59].

\section{Elements in Urgent Need of Improvement Upon the Establishment of a Unified Chinese Market}

Though the building of a national carbon market has been initiated, the policy conditions at the national level and the trading status in various pilot areas, as well as the regional differences between the pilot areas, are not mature enough to ensure the smooth operation of the national carbon market [60]. Therefore, at the special stage when the carbon pilots and the unified carbon market co-exist, it is of great importance for policy makers in relevant sectors to recognize the urgent elements in the process of building a national carbon market $[19,40]$, thereby promoting the national carbon market to enter a mature and stable status as soon as possible.

\subsection{Carbon Price}

As variances in carbon prices in pilot areas can block the connections in the carbon market [23], a unified price signal is key to shaping a national unified carbon market; nevertheless, a government-dominated mandatory linkage is likely to result in dysfunction of the carbon price mechanism. Therefore, Chen [61] and Jin et al. [62] proposed to adjust carbon prices via a series of moderate and progressive macro-control tools, such as punitive level, dynamic allocation, and a safety valve mechanism. However, Perkis et al. [63], upon conducting experimental research on the carbon emission right, found that, compared with the soft price cap, the hard price cap would 
make the carbon price stabilization mechanism more effective. Wei [64] proposed improving the price formation mechanism and introducing the price management mechanism through quota inter-temporal storage and project offset reduction while continuously evaluating the operating parameters of each system, seeking the optimal opportunities for market connection, facilitating the integration between subsystems, and gradually generating a unified price signal. In view of the uncertainties of carbon emissions in China, a set of quantity control tools based on price fluctuations shall be created and can be adjusted automatically between quota supply and market price, so as to form a stable price interval with clear expectation consisting of auction reserve price and trigger value $[65,66]$.

Jiang et al. [33] proposed that a market-oriented carbon market should be established based on enhanced macro-control to safeguard market effectiveness. Theoretically, a unified price signal can be achieved through pure market operation; however, considering the differences in resource endowments and levels of carbon market development in China's pilot areas, as well as the impact of local protectionism and the fact that the current carbon market mechanism of China is not yet mature, proper direct government intervention is indispensable for creating a national unified carbon emission right price, and differentiated regulatory policies for different regions are required $[49,66]$. While seeking actively to match with the international carbon market, China shall also strengthen its risk monitoring capability in its carbon market to avoid excessive price fluctuations in China's carbon market, especially the negative impact on emission reduction due to rising carbon quota price [9].

\subsection{Carbon Quota}

In view of the unified domestic carbon market, for a certain period in the future, both free and paid quota allocations will be adopted, while the proportion of free quota will be reduced gradually as the carbon market matures [22,56]. Chen and $\mathrm{Lu}[43]$ hold that the central government should set the differentiated regional adjustment coefficient based on a unified distribution method; each province and city shall, based on its own situation, select the adjustment coefficient and distribute the quota under the supervision of the central government. Zhang et al. [46] further proposed to make use of the differences in economic levels and resource endowments between China's central and western regions to allocate quotas more equitably in a broad sense, i.e., more quotas shall be allocated to the central and western regions to create more opportunities for low-cost emission reduction.

By observing the experiences of the international carbon market when regulating the quantity of reference carbon quota, there is usually no effective adjustment tool for a much-too-low carbon price, and there is excessive quota at the early stage of EU ETS. Hence, at the initial stage of quota allocation, scarcity of carbon quota shall be ensured; meanwhile, in view of China's rapid yet unstable economic and social development potential, a certain post-adjustment or diversified management mechanism shall be established to regulate the quota quantity in the market, so as to offset the uncertain risks more flexibly $[19,55,66]$. The inter-temporal quotas' reserve can effectively ease the fluctuation of carbon quota price at each stage. As to the issue that the carbon trading pilots will continue to operate in parallel after the launch of the national carbon market, Ji et al. [49] believes that, due to the differences in the methods of quota allocation between the pilots and the national carbon market, quota heterogeneity would occur in trading either between pilots or between pilots and the national market. Therefore, the pilot quotas should continue to be used in the short-term, and quotas between different pilots and between pilots and the national market can be exchanged via CCER. In view of the large differences in the regional development of China, China shall refer to the experiences of EU ETS members with different economic development levels, and differentiate carbon quotas in different regions of China [67].

In terms of specific adjustment methods, Jin et al. [62] and $\mathrm{Wu}$ [68] proposed that the state reserved quotas, selling of certified resource emission reductions, quota paid auctions, and repurchase by government funds should be adopted comprehensively to macro-control the carbon market. According to Duan and Pang [2], the initial quota allocation should be based mainly on free distribution and be supplemented by paid auctions, while some quotas should be reserved for new participants. However, 
Xiong et al. [54] noted that China should improve its production emission data, so that, with sufficient and credible data, it could gradually introduce the baseline quota allocation method, which can reflect more accurately the actual carbon intensity. Meanwhile, China should also consider rewarding companies that take initiatives to improve energy efficiency and emission reduction, thus redressing the negative influences of the traditional whipping method; the means of quota access could also gradually follow EU ETS and CA CAT, and the proportion of paid auction quotas should be increased. $\mathrm{Wu}[68]$ also proposed, from a more micro-industrial perspective, that the monopoly industries that rarely have competitors, such as electricity and petrochemicals, should adopt auction allocation to avoid either shifting costs to consumers or seeking profits by selling surplus quotas in the secondary market; high-carbon emission companies under greater competitive pressures should be entitled to a larger proportion of free carbon quotas.

\subsection{Total Amount and Carbon Emission Sources Coverage}

To increase the predictability of the carbon market, the carbon market shall be under total amount control strictly. Nevertheless, a fixed cap could also lead to more unpredictable emission reduction efforts by the carbon market mechanism. For China's eight pilots to be linked bilaterally, the most direct and effective approach is to set the carbon intensity-based cap, which will reduce the uncertainty of carbon quota price caused by economic growth to a certain extent; moreover, it is vital to shift gradually to the overall national level and establish a carbon market that is regulated under the long-term and sustainable total amount control target [18,69]. Jotzo and Löschel [14] pointed out that China could observe the experiences of Australia in setting a rolling cap and adjusting the cap according to market, economic, and technological development. Perthuis and Trotignon [53] proposed to imitate the central bank's model of monetary policy making, during which the right to set caps is handled over to a fully-independent and authoritative regulatory authority that operates based on a certain governance framework with clear long-term goals; meanwhile, sufficient free discretion should also be reserved to control short-term fluctuations. In view of the new normal state that China's economic development has entered, as well as the uneven development of various regions and industries, while setting the carbon cap, relevant departments need to take economic expansion potential and industrial development into consideration $[2,53]$.

The determination of the total amount target should not only consider the green gas emission control targets set for the national market or pilots at the macro-level but also consider the enterprises and emission sources covered by the emissions' trading system at the micro level. For example, EU ETS covers direct emission sources whereas CA CAT includes indirect emission sources from upstream and downstream companies. Therefore, when confirming the differences in the threshold values of pilots and the number of companies covered, much coordination is needed to unify the national carbon market. When determining the industries covered and the threshold values, it is necessary to investigate the production technologies, scales, and carbon emission distribution of various industries, so that most carbon emission sources are covered and that the number of emission source companies is correct for easy management. At the initial stage, large-scale emission sources with sound data storage and large emission reduction potential should be selected, and then, as the needs of market size and liquidity are met, more small-scale emission sources could be incorporated [3,37,46].

\subsection{Legal and Policy System}

As for the legal system, there are not yet clear laws and regulations at the national level in China, resulting in lack of guidance on top-level design for the national carbon market $[30,37]$. In comparison with the relatively mature carbon trading systems, such as EU ETS and CA CAT, China's carbon market laws are lacking in both quantity and quality. The construction of the carbon market legal system and the design of the carbon market mechanism are mutually supportive, thus, the two should be carried out in parallel $[2,40]$. In terms of formulating laws, it is suggested that comprehensive and clear laws that can clarify the legal status of the market. The laws should focus on the quota attributes, market 
supervision subjects, the rights and responsibilities of the parties involved in the transactions, and strict punishment. Meanwhile, relevant explanatory documents are to be issued to reveal details of each of the trading steps $[19,43,56,70]$.

Besides, the effectiveness of the carbon emissions market depends on a good monitoring, reporting, and verification (MRV) system [14]. Therefore, China's carbon market should establish a carbon emission data monitoring system and build the MRV talent team, improve the basic database and information disclosure system, enhance the timeliness and transparency of information, and strengthen the procedural and standardized construction of carbon trading [2,43,71]. It is also crucial to realize at an early stage the independent certification of the annual carbon emission report by the third-party carbon trading auxiliary agency, which will not only improve the credibility of the carbon market connection mechanism but also support more deeply the connection between the CCM and the world's trading markets $[48,56]$.

As for policy design, according to Zhang et al. [46], as China's carbon market covers a wide geographical range and involves many provinces and cities, it should observe the operational experiences of EU ETS and CA CAT in considering diversity for cross-regional policy design. Wei [64], Chen and Lu [43], as well as Zhao et al. [70] explored different policy models for different periods of carbon market operation; i.e., policy-making needs to take the phased nature into consideration. The design process should consider coordinating carbon market policies and other emission reduction policies, so that the vested interests of various departments can be crossed to maximize the effectiveness of policies; such coordination must be reflected at the international, central, and provincial levels $[9,71]$. Zhang et al. [40] pointed out that there are certain similarities between the Chinese and the EU carbon markets, and China should learn from the latter in setting the explicit and unified EU ETS general objectives, allowing a certain degree of flexible autonomy among members, and enabling timely and effective communication and feedback between the various parties in the carbon trading system.

\section{Connection between the Chinese and the World Carbon Market}

\subsection{Necessity and Significance of Connection}

\subsubsection{Economic Benefits}

The trading of carbon emission rights is a policy instrument to reduce the emission of greenhouse gases in a cost-effective way and by means of market operation. Most scholars believe that the successful connection of carbon markets will bring about considerable economic profit. Especially for the eight pilot projects, with quite different potentials and costs of emission reduction in China, connecting the pilot projects and forming a national carbon market can effective help in hitting the target of emission reduction and maximizing the cost effectiveness, with reasonable costs of emission reduction and on the basis of the utilization of difference [72,73]. Along with the continuous intensification of economic globalization, the economic ties between various countries are increasingly close. On the one hand, this provides favourable conditions for the connection of the global carbon market. On the other hand, this also promotes the realization of the connection [74]. Qi and Weng [75] found out that the globalized carbon trading market can reduce significantly the cost of emission reduction in countries in Annex I in the Kyoto Protocol. Hübler et al. [76] simulated the connection between the Chinese carbon trading market and EU ETS and concluded that the connection of the carbon markets is related closely to the welfare effect and quota transfer, and, even though the transmission of quota is restricted somewhat, the CCM would still benefit from it at all times. In addition, the expansion of carbon trading coverage and the increase of total quota after the connection can enhance the liquidity of the carbon market and enrich the options of emission reduction, thereby reducing both the cost of emission reduction and the volatility of carbon prices by taking advantage of the difference in resource endowment [77]. 


\subsubsection{Political Benefits}

In addition to cost advantages, there are political benefits from increased international climatic commitments and reduced international competition. The common challenges faced by various countries in the context of global climate degradation have driven these countries to move from competition to cooperation in the carbon market [30], and the political commitments of international climatic policies have become the most realistic benefit of connecting the trading systems of various countries. Moreover, the connection of carbon markets provides a framework for fulfilling "common but differentiated responsibilities" and can effectively reduce the pressure on countries to reduce emissions, while playing an important role in the future architecture of international climatic policies $[7,53,78]$. For China, a closer connection to the carbon trading of other countries can improve China's position in international climate negotiations [61]. At the micro-level, the establishment of a relatively uniform regulatory system on carbon emissions can avoid conflict of rules, prevent enterprises from moving from areas with strong carbon constraints to areas with weak carbon constraints, and, thus, prevent the occurrence of carbon leakage [79].

However, some scholars believe that, in addition to the above positive impacts, the connection of the carbon markets will also bring about such negative impacts as a more uneven distribution of social welfare and an unbalanced distribution of social benefits, the loss of free dominance and regulatory control over China's own carbon market system, and the loss of international competitiveness of Chinese energy-intensive industries [54,78].

\subsection{Matchmaking Mode}

Within the system of carbon emission trading, two carbon markets based on the total amount control and emission trading system accept each other's carbon quota in either a unidirectional or a multi-directional manner, thus forming the direct matchmaking of the carbon market. According to its trading direction, this direct matchmaking mode can be classified into three types: unilateral matchmaking, bilateral matchmaking, and multilateral matchmaking [9]. In the case of unidirectional cooperation, carbon trading prices would be adjusted automatically in both markets. The mode of unidirectional cooperation acts as the "experimental stage" for various parties of cooperation, which helps to coordinate the compatibility of the carbon trading system, and assists in timely discovery and adjustment of the problems in the matchmaking cooperation, but it makes it difficult to fully integrate and exert the liquidity and the advantages of emission reduction. In contrast with unidirectional cooperation, bidirectional matchmaking cooperation means that each carbon trading market approves the quota or credit used by the counterparty in the implementation of emission reduction. This is evidently the direction of future cooperation in the carbon trading market. However, due to the complexity of the issues involved, it is necessary for different countries and regions to sign a mandatory cooperation framework agreement after weighing the interests of various parties [78].

The indirect cooperation mode is to carry on the matchmaking cooperation with each other through CDM. If a relationship is established through a third party platform between the other two trading markets by leveraging either quota or credit, then some partial and unconventional connections would be attempted among different emission trading systems before an official connection is reached. Due to the difference in the priority rules and policies among different countries and regions, the potential incompatibility in the priority order of cost control, environmental effectiveness, and other factors would lead to the difference between different markets [9,52,80,81]. Direct connections may require all round trade-offs and international cooperation, so that only a small number of direct bilateral connections can achieve institutional coordination within a short period of time. Because the link of trade licensing systems can reduce compliance costs and increase market liquidity, people would be very interested in linking the trading system of carbon emission to the clean development mechanism and other credit systems. To ensure the coordination of key design elements in the future medium-term and long-term development, it is necessary to establish institutional cooperation at the early stage of 
connection. Therefore, certain policy steps and appropriate institutional architectures must be adopted to guide the connection of carbon markets [78].

\subsection{Compatibility Analysis of Carbon Market Connection}

Emission trading projects are usually combined with current policies. The coordination of the nature of reduction, the control mechanism of quota prices, and the rules of the market system have an important impact on all connected systems, as an essential element to be considered in promoting the matchmaking cooperation. The design of the carbon market must address its compatibility with other policies and calibrate key elements of connection to promote the wider application of various instruments of emission reduction [39,82,83]. According to the definition of matchmaking cooperation, i.e., the emission-reducing subjects can fulfil their contract-performing requirements by purchasing quotas from other carbon markets, Wang and Wei [77] pointed out that the rules and systems of the markets for matchmaking cooperation require a high degree of matching. Therefore, matchmaking cooperation does not require all parties to have the same systems and rules, but the design of some key rules may undermine the original design of emission reduction system, thus hindering matchmaking cooperation. Therefore, to ensure the compatibility of these elements in the process of carbon market connection, cooperation and coordination between two or more parties at the early stage of connection in terms of policy advancement and institutional framework is indispensable for achieving a more coherent connection in the carbon trading market.

Tuerk et al. [80] divided the connection elements into those that are easy to coordinate and those that are difficult to coordinate. Those that are easy to coordinate include MRV, storage rules, registrants, contract performance period, and quota allocation method, and those that are difficult to coordinate include overall goals and concrete modes of implementation, carbon credit offsetting, and cost control. Pang et al. [73] summarized the connection elements from another perspective: the contract compliance mechanism, price regulation mechanism, storage and loan rules, and offsetting mechanism should be completely consistent, and the upper limit of total quantity and the distribution of quota needs to be mutually recognized. Such technical factors as an MRV mechanism and registration system should be developed in a coordinated manner insofar as it is possible. In contrast, other elements, such as system coverage scope, have no direct impact on the system connection, so they need not be highly coordinated. Of the elements mentioned above, Zhang et al. [9] emphasized the importance of coordination of carbon quota allocation modes for the connection of carbon trading markets. Considered in the short-run in terms of political obstacles and matchmaking costs, the market of carbon emission trading under total quantity control can make it easier to swap a country's carbon quota with the contract-performing units stipulated in the Kyoto Protocol. In addition, Flachsland [83] pointed out that the process of choosing which carbon market to connect with is very crucial, and a range of variables, such as geographic proximity, economic benefits and net welfare of alternative carbon markets, need to be considered when making the choice.

According to Chen [65], the essential condition for the connection of two carbon markets is to judge whether they have the same degree of emission reduction. The connection of price management mechanisms is the basic content of the connection of carbon markets. Asymmetric information, different transaction costs, external shocks, and political problems can all lead to price volatility in the carbon market. The successful connection of carbon markets is marked by the convergence of carbon prices and the improvement of the authenticity of carbon market emission reduction. These two indicators should be regarded as the ultimate goal of the macro-regulation of the national carbon market. Mackay et al. [84] also pointed out that, during the international climate negotiations, a uniform carbon price would provide a focus for common international commitments, making it easier for different carbon trading markets to predict their respective development trends while reducing their gap. The conclusions of Johannsdottir and Mcinerney [85] are more comprehensive. They concluded that the existence of the following three key steps would make the framework of international carbon market connection more effective: (1) Connect the carbon markets of all countries to attain the goal 
of promoting the fulfilment of the emission reduction commitments of these countries;(2).Establish relevant rules on the international transfer of carbon emission reduction; and (3) Take certain measures to narrow the gaps between the carbon pricing systems of different countries.

\subsection{Successful International Cases in the Connection of Carbon Markets}

At the early stage, the carbon markets of various countries or regions are different in terms of industrial coverage, quota distribution, and MRV. The design of the carbon market system is driven mostly by domestic political and economic demand. Less or even no consideration is given to the problem of connection between the carbon markets [3]. However, there have been many successful international cases in the connection of carbon markets, including the attempts of matchmaking cooperation of carbon trading markets between the EU and Norway, Iceland and Liechtenstein, the EU and Australia, and California (USA) and Quebec (Canada).

\subsubsection{The Position and Connection of EU ETS}

As the world's largest carbon trading market before 2017 [22,86], the EU ETS's spot, futures and options tools accounted for more than $80 \%$ of the global market [87]. EU ETS is the first carbon trading system which multi-country has participated in [88] and it has always played a leading role in cooperating with other carbon trading markets. EU ETS advocates the formation of a bottom-up global carbon market by connecting carbon markets in different regions, thereby achieving a new model of global climate cooperation by leveraging the cooperation of carbon trading markets. EU ETS has pointed out that the carbon trading markets cooperating with the EU ETS in a matchmaking way must be characterized by system coordination, i.e., consistent environmental integrity. Therefore, the counterparty generally uses the EU carbon market rules as a standard for adjustment to improve the coordination of the rules between both parties. Generally speaking, the EU ETS starts with unidirectional cooperation consisting of several stages and transits gradually to bidirectional cooperation, which provides the experimental stage and adjustment period for the matchmaking cooperation of both parties and minimizes the impact and influence of the market difference on each other's carbon trading market [78].

The connection of the carbon market between the EU and Norway, Iceland, and Liechtenstein actually means that the EU ETS has absorbed the carbon markets of these three countries [48]. The main purpose is to solve the problems of industrial competition and carbon leakage faced by the EU and these countries in economic and trade exchanges. The EU ETS requires that the directive is incorporated into the Protocol of the European Economic Area. Meanwhile, Norway, Iceland, and Liechtenstein need to submit their national allocation plans for approval by EFTA regulators [89]. The emission reduction at the first stage involved more than 10,000 companies in power generation, refineries, steel mills, cement, glass, ceramics, paper making, and brick making [90]. In 2012, more than 2000 airlines around the world were also incorporated into the EU's system of aviation carbon trading. Operators of all commercial and non-commercial flights must be responsible for the carbon emissions of their aircraft within the European Economic Area [91,92].

\subsubsection{The Position and Connection of US Carbon Emissions Trading System}

The US carbon emissions trading system has a distinctive feature. There is no unified trading system across the country, and each region chooses its own appropriate emission reduction plan. The North American secondary carbon market is dominated by the Chicago Climate Exchange (CCX) and its subsidiary Futures Exchange (CCFE) [87]. Besides, as a global leader in the carbon market and climate change [22], California established a mandatory reporting system for greenhouse gases in 2008. Furthermore, from the perspective of coverage, the CA CAT is the second largest emissions trading system after the EU ETS [88], and has established accounting reporting methods for 20 industries. In 2013, the California carbon market was officially launched, which covers six greenhouse gases and accounts for $85 \%$ of California's greenhouse gas emissions [93]. 
Different from the link in EU ETS, the connection of carbon markets between California and Quebec is a matchmaking model on an equal footing. California and Quebec signed the Agreement of Matchmaking Cooperation, which coordinates and controls the two carbon markets through the establishment of an advisory board and tries to bridge institutional difference through consultation and negotiation. Diodati and Purdon [94] pointed out that, because California had a larger carbon emission and a lower carbon quota price before the carbon markets were connected, the quota price of Quebec's carbon trading market was impacted strongly and declined after the connection. As a whole, California has benefited more from the cooperation.

\subsection{Feasibility of Connecting CCM with International Carbon Market}

In terms of law, Duan and Pang [2] studied the basic laws and regulations of the trading system of carbon emission rights of EU ETS, RGGI (USA), NZ ETS (New Zealand), CA CAT, and ACTM (Australia), and found that all these trading systems were based on foregoing legislation that stipulated the macro market positioning and quota attributes. Some of these systems will be followed by specific details promulgated at the technical level of trading, such as the method of quota allocation, monitoring of emissions, MRV, and supervision of quota trading. Because of the limitation from insufficient laws and regulations, the penalties for breach of contract in various pilot projects in China are generally laxer than are those of the EU ETS and the CA CAT. Therefore, the laws and regulations applicable to the national carbon market can, to a certain extent, alleviate the problem of the penalties not being strong enough $[15,62]$. Both EU ETS and CA CAT promulgated basic laws and regulations and made great efforts to publicize them before their operation, and later attached a large number of technical explanatory documents providing detailed legal and regulatory information on specific steps, such as the method of quota allocation, monitoring of emissions, MRV, and supervision of quota trading. At present, most of the rules of various pilot projects in China are formulated in too general a way and lack sufficient detailed and specific description [2,56]. Therefore, there is insufficient legal guarantee for connecting the CCM and other carbon markets at present.

In terms of carbon quota allocation, Xiong et al. [47] expounded and analysed seven of the pilot projects in China, omitting Fujian, and the three quota methods used by three stages of the EU ETS and the CA CAT-namely, historical emission method, historical intensity method, and industry benchmark method-and found that the historical emission method was used only in the first two stages of the EU ETS, and the base-line method was used in the third stage and in the CA CAT. In contrast, due to the short preparatory period for the establishment of various pilot projects and the limitation from the defects of historical data, China tends to adopt the historical emission method and historical density method, or uses various methods together, to coordinate the dynamic relationship between economic growth, industrial transformation, and emission control. The settings of the upper limit of emissions by both the EU ETS and the CA CAT show a downward trend [63,95]. California also set a certain quota to form a reserve mechanism of price control, thus ensuring that the price of quota auction can be controlled within a reasonable range. By analysing the changes in the proportions of quota auction of the EU ETS and the CA CAT at various stages of development, Xiong et al. [54] also found that both had a high free allocation proportion and a low auction proportion at the initial stage and that the two proportions began to reverse along with the gradual maturity of the market operation; the quota of the CA CAT could also be acquired via sale at a fixed price. They classified the industries for emission management into three grades: high risk, medium risk, and low risk. The high-risk industries always obtain 100\% free allocation quota. Similarly, Qi et al. [15] compared the difference between Chinese pilot projects and the EU ETS and the CA CAT from 12 perspectives, such as access criteria, quota allocation adjustment, and storage and regulation. The contrasting results also show that the proportion of the auction of carbon emission quotas by various pilot projects in China is much lower than those in the EU and California, but it is similar to that at Stage I and Stage II of the EU ETS. All the above studies show that there is an obvious difference between China and the EU ETS and the CA CAT in the allocation mode and proportion of quota [96]. If we want to successfully 
connect the CCM with the international carbon market in the future, we still need to bring the relevant quota system closer to the carbon markets of other countries.

\subsection{Insufficient of CCM Compared to the International Carbon Market and Improvement Measures in the near Future}

Based on the above analysis, we find that China's carbon market is still in the infrastructure construction period compared with other international carbon markets, and the experience is relatively insufficient.

\subsubsection{Insufficient Market Participation}

Due to the lack of willingness and ability of the main control emitter, the low transaction activity has become the key to restricting the allocation of resources in CCM. Moreover, the market mechanism and related supporting policies in the market construction failed to develop simultaneously. CCM should learn from the US CCX to actively combine financial products with carbon emission reduction, and cultivate regional carbon asset management service companies, thereby promoting the use of market means to solve environmental problems.

\subsubsection{Unreasonable Method and Mechanism of Quota Allocation}

At present, CCM adopts Historical emission or Historical intensities method. By contrast, EU ETS and CA CAT adopt a more scientific and fair method: Industry benchmarks. To achieve a successful connection with the international carbon market, China's carbon market should gradually shift to the Industry benchmarks method. It is also necessary to promote the construction of the carbon quota system in stages, that is to say, the vast majority of the initial carbon allowances are allocated to enterprises with free of charge, and more shares are used by public auctions in the later stage.

\subsubsection{Strict Control Mechanism for Carbon Emission Data}

Compared with other mature carbon markets, CCM data is insufficient in quality and quantity, which makes it impossible to provide a qualified data base for carbon quota allocation. Therefore, relevant departments should comprehensively control from the perspective of data of generation, collection, reporting, approval and use. Simultaneously, there is a need to promote the data preparation work of the industry that has not systematically collected emission data. In addition, it is vital to ensure the quality of emission data and improve industry coverage of carbon emissions data.

\subsubsection{Improving Legal Basis of the Carbon Market}

The laws and regulations that are compatible with the CCM have not been detailed and the regulatory effects are insufficient. Therefore, in the process of carbon market construction and connection with other carbon markets, the research work on carbon trading legislation is to be further strengthened to clarify the responsibilities and obligations of the competent authorities, enterprises, verification agencies, trading institutions, financial institutions and other participating entities. Moreover, it is of great importance to promote the simultaneous development and integration of relevant laws and technical support work such as MRV and quota allocation methods. Thus, CCM is bound and protected by law in its own operations and in connection with other carbon markets.

In addition, some scholars have summarized the following problems with the CCM: an unclear target of quantitative control; lack of sustainability; the secondary carbon market of China is not active enough and is insufficiently interactive with the primary market and has a low degree of market orientation; the management mechanism of MRV is short of top-level design and micro-technology support; the market orientation degree of carbon finance is not high, with a weak ability of risk control; and the emission data of enterprises are insufficient and non-transparent. All will reduce the market efficiency. Whether the willingness of the two matchmaking parties is strong is also a key factor for 
the realization of the connection of carbon markets. The above factors may create an insurmountable obstacle to the connection between the CCM and the international carbon market $[29,35,42,50,58,62]$.

\section{Conclusions and Outlook}

Based on the both domestic and foreign literature on carbon markets, this paper first summarizes the status-quo of China's carbon trading pilots in terms of legal mechanism, carbon quota allocation, and market transaction, and points out that all three initiatives are only emerging and need to improve continuously before growing into a mature carbon market. Then, the paper continues to analyse China's unified carbon market from the perspectives of carbon price, carbon quota, total amount, emission sources' coverage, and legal system; and identifies the existing problems in the current carbon market as well as countermeasures. It also suggests that China's carbon market should generate a unified carbon price signal and strengthen risk monitoring capability; create a unified quota allocation method and increase the proportion of carbon quota auctions; set a clear carbon cap at the national level; coordinate emission sources in different regions and industries; issue clear laws and regulations and explanatory documents; enhance the timeliness and transparency of the MRV system; and consider the diversity, phased nature, and compatibility of carbon market policies to guide and optimize the unification of China's carbon market and its integration with the world carbon market. Last but not least, based on the analysis of the necessity of carbon market connection, connection mode, and compatibility, this paper summarizes the feasibility of connecting the Chinese and the international carbon markets. The second part of the paper mentions the factors required improvement. These include clarifying the top-level laws and regulations, illustrating the steps of the carbon market at the micro-level, identifying the unified measurement method of carbon quota, and gradually enlarging the proportion of the carbon quota auction. These are of special importance for smooth integration of the Chinese and the international carbon markets.

The existing literature on carbon market linkages mostly focuses on quota allocation, law and regulation, and carbon price. Therefore, the research contents are to be extended to the elements such as carbon finance and MRV, where EU ETS and other markets has matured, but CCM has not yet been systematically involved. At the same time, based on the existing research, the research should be more detailed, e.g., how to choose the connection object for maximizing the carbon market benefits, how to ensure the equivalence of carbon quotas between the two markets, and how to promote the coordination and stability of carbon prices among in the process of connection.

Author Contributions: F.D. conceived the idea of this paper; Y.H. and F.D. wrote the paper.

Funding: This work was supported by the National Natural Science Foundation of China (Grant No. 71573254), Jiangsu Funds for Social Science (Grant No. 17JDB004), Jiangsu Education Science Project (Grant No. B-b/2015/01/027), and Key Project of Postgraduate Education and Teaching Reform in Jiangsu Province (JGZZ18_047).

Conflicts of Interest: The authors declare no conflict of interest.

\section{References}

1. Dong, F.; Wang, Y.; Su, B.; Hua, Y.; Zhang, Y. The process of peak $\mathrm{CO}_{2}$ emissions in developed economies: A perspective of industrialization and urbanization. Resour. Conserv. Recycl. 2019, 141, 61-75. [CrossRef]

2. Duan, M.; Pang, T. Basic elements of emissions trading scheme. China Popul. Resour. Environ. 2013, 23, 110-117. (In Chinese)

3. Egenhofer, C. The making of the EU emissions trading scheme. Eur. Manag. J. 2007, 25, 453-463. [CrossRef]

4. Peng, S.; Chang, Y.; Zhang, J. Considerations on some key issues of carbon market development in China. China Popul. Resour. Environ. 2014, 24, 1-5. (In Chinese) [CrossRef]

5. Dong, F.; Dai, Y.; Zhang, S.; Zhang, X.; Long, R. Can a carbon emission trading scheme generate the Porter effect? Evidence from pilot areas in China. Sci. Total Environ. 2019, 653, 565-577. [CrossRef]

6. Hultman, N.E.; Pulver, S.; Guimarães, L.; Deshmukh, R.; Kane, J. Carbon market risks and rewards: Firm perceptions of CDM investment decisions in Brazil and India. Energy Policy 2012, 40, 90-102. [CrossRef] 
7. Lanzi, E.; Chateau, J.; Dellink, R. Alternative approaches for levelling carbon prices in a world with fragmented carbon markets. Energy Econom. 2012, 34, S240-S250. [CrossRef]

8. Li, H.; An, H. How does the coal stock market, carbon market and coal price co-movement with each other in China: A co-movement matrix transmission network perspective. Energy Procedia 2017, 105, 3479-3484. [CrossRef]

9. Zhang, W.; Ma, H.; Yang, L. The linkage of international carbon market and its implication to China. Finance Econ. 2014, 2, 122-130. (In Chinese)

10. Dong, F.; Bian, Z.; Yu, B.; Wang, Y.; Zhang, S.; Li, J.; Su, B.; Long, R. Can land urbanization help to achieve $\mathrm{CO}_{2}$ intensity reduction target or hinder it? Evidence from China. Resour. Conserv. Recycl. 2018, 134, $206-215$. [CrossRef]

11. BP. Statistical Review of World Energy; BP: London, UK, 2018.

12. Dong, F.; Yu, B.; Tergel, H.; Dai, Y.; Wang, Y.; Zhang, S.; Long, R. Drivers of carbon emissions intensity change in China. Resour. Conserv. Recycl. 2018, 129, 187-201. [CrossRef]

13. Jiang, J.J.; Ye, B.; Ma, X.M. The construction of Shenzhen' s carbon emission trading scheme. Energy Policy 2014, 75, 17-21. [CrossRef]

14. Jotzo, F.; Löschel, A. Emissions trading in China: Emerging experiences and international lessons. Energy Policy 2014, 75, 3-8. [CrossRef]

15. Qi, S.; Wang, B.; Zhang, J. Policy design of the Hubei ETS pilot in China. Energy Policy 2014, 75, 31-38. [CrossRef]

16. Ministry of Foreign Affairs of P.R.C. (MFA). U.S.-China Joint Presidential Statement on Climate Change; MFA: Beijing, China, 2016. (In Chinese)

17. Development and Reform Commission of P.R.C. (DRC). Launched the National Carbon Emission Trading Market in 2017; DRC: Beijing, China, 2017. (In Chinese)

18. Li, W.; Zhang, Y.; Lu, C. The impact on electric power industry under the implementation of national carbon trading market in China: A dynamic CGE analysis. J. Clean. Prod. 2018, 200, 511-523. [CrossRef]

19. Liu, Z.; Geng, Y.; Dai, H.; Wilson, J.R.; Xie, Y.; Wu, R.; You, W.; Yu, Z. Regional impacts of launching national carbon emissions trading market: A case study of Shanghai. Appl. Energy 2018, 230, 232-240. [CrossRef]

20. Economic Information Daliy (EID). National Carbon Market "Three-Step" Roadmap Started; EID: Beijing, China, 2017. (In Chinese)

21. Development and Reform Commission of P.R.C. (DRC). Notice of the General Office of the National Development and Reform Commission on Doing a Good Job in the National Carbon Emissions Trading Market; DRC: Beijing, China, 2016. (In Chinese)

22. ICAP. Emission Trading Worldwide: Status Report 2018; ICAP: Berlin, Germany, 2018.

23. WB. State and Trends of Carbon Pricing 2018; WB: Washington, DC, USA, 2018.

24. Xinhua, China's Carbon Trading Transaction Value Exceeds 6 bln yuan. Available online: http://www.china. org.cn/business/2018-11/27/content_74212670.htm (accessed on 23 February 2019).

25. Gao, S.; Li, M.Y.; Duan, M.S.; Wang, C. International carbon markets under the Paris Agreement: Basic form and development prospects. Adv. Clim. Chang 2019, in press. [CrossRef]

26. Du, H.; Li, B.; Brown, M.A.; Mao, G.; Rameezdeen, R.; Chen, H. Expanding and shifting trends in carbon market research: A quantitative bibliometric study. J. Clean. Prod. 2015, 103, 104-111. [CrossRef]

27. Liu, L.; Chen, C.; Zhao, Y.; Zhao, E. China's carbon-emissions trading: Overview, challenges and future. Renew. Sustain. Energy Rev. 2015, 49, 254-266. [CrossRef]

28. Song, Y.; Liu, T.; Li, Y.; Liang, D. Region division of China's carbon market based on the provincial municipal carbon intensity. J. Clean. Prod. 2017, 164, 1312-1323. [CrossRef]

29. Weng, Q.; He, X. A review of China's carbon trading market. Renew. Sustain. Energy Rev. 2018, 91, 613-619. [CrossRef]

30. Alberola, E.; Chevallier, J. European carbon prices and banking restrictions: Evidence from Phase I (2005-2007). Energy J. 2009, 30, 51-79. [CrossRef]

31. Feng, Z.H.; Zou, L.L.; Wei, Y.M. Carbon price volatility: Evidence from EU ETS. Appl. Energy 2011, 88, 590-598. [CrossRef]

32. Feng, Z.H.; Wei, Y.M.; Wang, K. Estimating risk for the carbon market via extreme value theory: An empirical analysis of the EU ETS. Appl. Energy 2012, 99, 97-108. [CrossRef] 
33. Jiang, Y.; Lei, Y.L.; Yang, Y.Z.; Wang, F. Factors affecting the pilot trading market of carbon emissions in China. Petrol. Sci. 2018, 15, 1-9. [CrossRef]

34. Chang, K.; Chen, R.; Chevallier, J. Market fragmentation, liquidity measures and improvement perspectives from China's emissions trading scheme pilots. Energy Econ. 2018, 75, 249-260. [CrossRef]

35. Dong, F.; Long, R.; Yu, B.; Wang, Y.; Li, J.; Wang, Y.; Dai, Y.; Yang, Q.; Chen, H. How can China allocate $\mathrm{CO}_{2}$, reduction targets at the provincial level considering both equity and efficiency? Evidence from its Copenhagen accord pledge. Resour. Conserv. Recycl. 2018, 130, 31-43. [CrossRef]

36. Zhao, X.G.; Jiang, G.W.; Li, A.; Yun, L. Technology, cost, a performance of waste-to-energy incineration industry in China. Renew. Sustain. Energy Rev. 2016, 55, 115-130.

37. China Industry Research Network (CIRN). 2018 Edition of China's Carbon Trading Market Status Survey and Development Prospect Analysis Report; CIRN: Beijing, China, 2017. (In Chinese)

38. Fan, J.H.; Todorova, N. Dynamics of China's carbon prices in the pilot trading phase. Appl. Energy 2017, 208, 1452-1467. [CrossRef]

39. Jiang, J.; Xie, D.; Ye, B.; Shen, B.; Chen, Z. Research on China's cap-and-trade carbon emission trading scheme: Overview and outlook. Appl. Energy 2016, 178, 902-917. [CrossRef]

40. Zhang, M.; Fan, D.; Dou, Y. Analysis on EU carbon market progress and its reference to China. Environ. Prot. 2014, 42, 64-66.

41. Ibikunle, G.; Andros, G.; Hoepner, A.G.F.; Rhodes, M. Liquidity and market efficiency in the world's largest carbon market. Br. Account. Rev. 2016, 48, 431-447. [CrossRef]

42. Zhao, X.G.; Jiang, G.W.; Nie, D.; Chen, H. How to improve the efficiency of carbon trading: A perspective of China. Renew. Sustain. Energy Rev. 2016, 59, 1229-1245. [CrossRef]

43. Cheng, X.; Lu, S. Basic elements and design of China's future unified national emissions trading scheme. Reg. Econ. Rev. 2016, 6, 92-98. (In Chinese)

44. Lin, W.; Liu, B. Chinese carbon market: Current status and future perspectives. J. Tsinghua Univ. 2015, 55, 1315-1323. (In Chinese)

45. Perdan, S.; Azapagic, A. Carbon trading: Current schemes and future developments. Energy Policy 2011, 39, 6040-6054. [CrossRef]

46. Zhang, D.; Karplus, V.J.; Cassisa, C.; Zhang, X. Emissions trading in China: Progress and prospects. Energy Policy 2014, 75, 9-16. [CrossRef]

47. Xiong, L.; Shen, B.; Qi, S.; Price, L. Assessment of allowance mechanism in China's carbon trading pilots. Energy Procedia 2015, 75, 2510-2515. [CrossRef]

48. Tang, L.; Wu, J.; Yu, L.; Bao, Q. Carbon emissions trading scheme exploration in China: A multi-agent-based model. Energy Policy 2015, 81, 152-169. [CrossRef]

49. Ji, C.; Hu, Y.; Tang, B. Research on carbon market price mechanism and influencing factors: A literature review. Nat. Hazards 2018, 92, 761-782. [CrossRef]

50. Zhang, Y.J.; Wang, A.D.; Tan, W. The impact of China's carbon allowance allocation rules on the product prices and emission reduction behaviors of ETS-covered enterprises. Energy Policy 2015, 86, 176-185. [CrossRef]

51. Jiang, R. Carbon trading and China's carbon market outlook. China Econ. Rep. 2017, 5, 52-56. (In Chinese)

52. Flachsland, C.; Marschinski, R.; Edenhoffer, O. To link or not to link: Benefits and disadvantages of linking cap-and-trade systems. Clim. Policy 2009, 9, 358-372. [CrossRef]

53. Perthuis, C.D.; Trotignon, R. Governance of $\mathrm{CO}_{2}$ markets: Lessons from the EU ETS. Energy Policy 2014, 75, 100-106. [CrossRef]

54. Xiong, L.; Shen, B.; Qi, S.; Price, L.; Ye, B. The allowance mechanism of China's carbon trading pilots: A comparative analysis with schemes in EU and California. Appl. Energy 2017, 185, 1849-1859. [CrossRef]

55. Carbon Trading Net. Available online: http://www.tanpaifang.com/tanhangqing/ (accessed on 6 June 2018). (In Chinese).

56. Yi, L.; Li, Z.; Yang, L.; Liu, J.; Liu, Y. Comprehensive evaluation on the maturity of China's carbon markets. J. Clean. Prod. 2018, 198, 1336-1344. [CrossRef]

57. Chen, B. The supervision dilemma of China's carbon market financialization and its system perfection. Secur. Market Herald 2017, 9, 69-78. (In Chinese)

58. Lo, A.Y.; Yu, X. Climate for business: Opportunities for financial institutions and sustainable development in the Chinese Carbon Market. Sustain. Dev. 2015, 23, 369-380. [CrossRef] 
59. Charles, A.L.; Darn, O.; Fouilloux, J. Market efficiency in the European carbon markets. Energy Policy 2013, 60, 785-792. [CrossRef]

60. Munnings, C.; Morgenstern, R.D.; Wang, Z.; Liu, X. Assessing the design of three carbon trading pilot programs in China. Energy Policy 2016, 96, 688-699. [CrossRef]

61. Chen, B. The establishment of China's national carbon market and its macro-control strategy. China Popul. Resour. Environ. 2013, 23, 9-15. (In Chinese)

62. Jin, M.; Kong, L.; Wang, Z. Analysis of the current status and problems of the carbon emission trading pilots in China. Environ. Prot. Sci. 2016, 42, 134-140. (In Chinese)

63. Perkis, D.F.; Cason, T.N.; Tyner, W.E. An experimental investigation of hard and soft price ceilings in emissions permit markets. Environ. Resour. Econ. 2016, 63, 1-16. [CrossRef]

64. Wei, Q. Study on the pathway of China to mitigate emissions based on the compatibility of carbon tax and ETS. China Popul. Resour. Environ. 2015, 5, 35-43. (In Chinese)

65. Chen, B. Research on linkage of China's ETS and macro-control mechanism. China Popul. Resour. Environ. 2015, 10, 18-22. (In Chinese)

66. Jotzo, F. Emissions Trading in China: Principles, Design Options and Lessons from International Practice; CCEP Working Paper 1303; Crawford School of Public Policy, Australian National University: Canberra, Australia, 2013.

67. Wang, Q.; Li, J. China's regional carbon emission allowance prices regulation mechanism based on TVP model. China Popul. Resour. Environ. 2016, 26, 31-38. (In Chinese)

68. Wu, X. Research on the Allocation Method of Total Carbon Emission from the National Level to the Enterprise Level Constrained by Peak Target. Master's Thesis, Tianjin University of Technology, Tianjin, China, 2016. (In Chinese).

69. Quemin, S.; Wang, W. Overview of Climate Change Policies and Development of Emissions Trading in China; Les Cahiers de la Chaire Economie du Climat Information and Debate Series; International Nuclear Information System: Paris, France, 2014.

70. Zhao, X.G.; Wu, L.; Li, A. Research on the efficiency of carbon trading market in China. Renew. Sustain. Energy Rev. 2017, 79, 1-8. [CrossRef]

71. Duan, M.; Zhou, L. Key issues in designing China's national carbon emissions trading system. Econ. Energy Environ. Policy 2017, 6, 55-72. [CrossRef]

72. Fang, G.; Liu, M.; Tian, L.; Fu, M.; Zhang, Y. Optimization analysis of carbon emission rights allocation based on energy justiced: The case of China. J. Clean. Prod. 2018, 202, 748-758. [CrossRef]

73. Pang, T.; Zhou, L.; Duan, M. Study on the linking of China's emissions trading pilot schemes. China Popul. Resour. Environ. 2014, 24, 6-12. (In Chinese)

74. Mehling, M.; Haites, E. Mechanisms for linking emissions trading schemes. Clim. Policy 2009, 9, 169-184. [CrossRef]

75. Qi, T.; Weng, Y. Economic impacts of an international carbon market in achieving the INDC targets. Energy 2016, 109, 886-893. [CrossRef]

76. Hübler, M.; Voigt, S.; Löschel, A. Designing an emissions trading scheme for China? An up-to-date climate policy assessment. Energy Policy 2014, 75, 57-72. [CrossRef]

77. Wang, L.; Wei, Q. The inspiration and reference for China based on preliminary study of emission trading schemes linkage. Ecol. Econ. 2016, 32, 53-57. (In Chinese)

78. Jaffe, J.L.; Stavins, R.N. Linking a U.S. Cap-and-Trade System for Greenhouse Gas Emissions: Opportunities, Implications, and Challenges. SSRN Electron. J. 2008, 554. [CrossRef]

79. Stavins, R.N. Addressing climate change with a comprehensive U.S. Cap-and-Trade System. Soc. Sci. Electron. Publ. 2008, 24, 298-321. [CrossRef]

80. Tuerk, A.; Mehling, M.; Flachsland, C.; Ganasterk, W. Linking carbon markets: Concepts, case studies and pathways. Clim. Policy 2009, 9, 341-357. [CrossRef]

81. Burtraw, D.; Palmer, K.L.; Munnings, C.; Weber, P.; Woerman, M. Linking by Degrees: Incremental Alignment of Cap-And-Trade Markets. RFF Discussion Paper. 2013. Available online: https://papers.ssrn.com/sol3/ papers.cfm?abstract_id=2249955 (accessed on 29 April 2019).

82. Chang, Y.C.; Wang, N. Environmental regulations and emissions trading in China. Energy Policy 2010, 38, 3356-3364. [CrossRef] 
83. Flachsland, C.; Luderer, C.; Steckel, G.; Knopf, J. International emissions: Trading and the global deal. Diabetes Care 2015, 28, 33-39.

84. MacKay, D.J.C.; Cramton, P.; Ockenfels, A.; Stoft, S. Price carbon-I will if you will. Nature 2015, 526, 315-316. [CrossRef]

85. Johannsdottir, L.; Mcinerney, C. Calls for carbon markets at COP21: A conference report. J. Clean. Prod. 2016, 124, 405-407. [CrossRef]

86. Karpf, A.; Mandel, A.; Battiston, S. Price and network dynamics in the European carbon market. J. Econ. Behav. Organ. 2018, 153, 103-122. [CrossRef]

87. Mizrach, B. Integration of the global carbon markets. Energy Econ. 2012, 34, 335-349. [CrossRef]

88. Fu, J.Y.; Zhang, Y.F. The Link Mechanism of International Carbon Emission Trading System and Its Enlightenment to China. Environ. Prot. Circ. Econ. 2016, 4, 4-11. (In Chinese)

89. Chan, H.S.; Li, S.; Zhang, F. Firm competitiveness and the European Union emissions trading scheme. Energy Policy 2013, 63, 1056-1064. [CrossRef]

90. European Commission (EC). Emission Trading: Commission Announces Linkage EU ETS with Norway, Iceland and Liechtenstein; EC: Brussels, Belgium, 2007.

91. Zhang, L.; Li, Y.; Jiab, Z. Impact of carbon allowance allocation on power industry in China's carbon trading market: Computable general equilibrium based analysis. Appl. Energy 2018, 229, 814-827. [CrossRef]

92. Ministry of Commerce of the P.R.C. (MC). Carbon Emissions Trading Data Shows EU Has Lower Carbon Emissions in 2014; MC: Beijing, China, 2015. (In Chinese)

93. Liu, H.Y.; Zheng, S. The Construction of American Carbon Market and Its Enlightenment to China. China Econ. Trade Herald 2014, 8, 7-8. (In Chinese)

94. Diodati, M.L.N.; Purdon, M. Political Uncertainty or Carbon Leakage State of California-Quebec Carbon Market Since the August 2016 Auction Sale; IQ Carbone Research Note; IQ Carbone: Quebec, Canada.

95. Dormady, N.; Healy, P.J. The consignment mechanism in carbon markets: A laboratory investigation. J. Commodity Mark. 2018, 7, 1-15. [CrossRef]

96. Liao, Z.; Zhu, X.; Shi, J. Case study on initial allocation of Shanghai carbon emission trading based on Shapley value. J. Clean. Prod. 2015, 103, 338-344. [CrossRef] 